\title{
Dicrotrichura tricincta gen. et spec. nov.: A new tantulocaridan (Crustacea: Maxillopoda) from the Mediterranean deep waters off Corsica*
}

\author{
Rony Huys \\ Marine Biology Section, Zoology Institute, State University of Gent, K.L. Ledeganckstraat 35, B-9000 Gent, \\ Belgium and Delta Institute for Hydrobiological Research, Vierstraat 28, 4401 EA Yerseke, The Netherlands
}

Keywords: Tantulocarida, Dicrotrichura tricincta gen. et sp. nov., Mediterranean, deep water

\begin{abstract}
Summary
The new genus and species, Dicrotrichura tricincta, is described from deep mud $(1220 \mathrm{~m})$ in the Ligurian Sea (western Mediterranean). It is the first tantulocaridan not found to be attached to a crustacean host but free living in the sediment. It is assigned to the Deoterthridae on the basis of the absence of a rostrum, the abdominal segmentation and the characteristic cephalic pore pattern. It can be distinguished from all known tantulocaridans in the presence of peculiar, bi-articulated caudal setae and the difference in thoracopodal setation between leg 2 and legs 3-5. Some new structures located on the attachment disc are described for the first time. $D$. tricincta is the second tantulocaridan to be recorded from the Mediterranean.
\end{abstract}

\section{Résumé}

Dicrotrichura tricincta n. g., n. sp. est le second Tantulocaride connu provenant de la Méditerranée. Il provient de la vase profonde $(1220 \mathrm{~m})$ de la Mer Ligurienne (Méditerranée occidentale). $D$. tricincta est le premier tantulocaride vivant libre dans le sédiment, et non attaché à un Crustacé hôte. L'absence d'un rostre, la segmentation abdominale et le patron caractéristique des pores céphaliques le classent dans la famille des Deoterthridae. $D$. tricincta se distingue de tous les Tantulocarides connus par la présence de soies caudales bi-articulées et par la différence entre la position et le nombre des soies sur les thoracopodes 2 et 3 à 5 . Une description est donnée de structures nouvelles sur le disque d'attachement.

\section{Introduction}

Since Boxshall \& Lincoln (1983) formally established the class Tantulocarida to accommodate the small-sized maxillopodan genera Basipodella Becker and Deoterthron Bradford \& Hewitt, the number of species has raised to 17 , divided at present in nine genera and five families (Boxshall \& Lincoln 1987; Huys in press). All tantulocaridans hitherto known are obligate ectoparasites of other crustaceans. Most species show a high level of host specificity and utilize harpacticoids, tanaids or isopods as hosts although a few species are known to parasitize ostracods and cumaceans. Boxshall \& Lincoln (1987) provide an excellent analysis of the highly abbreviated life cycle which includes an infective tantulus larva, a swollen sac-like female and a freeswimming male. Starobogatov's (1986) untenable proposal to group the Tantulocarida (as a superorder Basipodelliformii) together with the gymnoplean copepods in the infraclass Calanioini was rejected by Grygier \& Sieg (1988) and Boxshall \& Huys (1989). The latter authors, inspired by the homology of the male tantulocaridan penis, suggested instead that their relationships may lie with the 'thecostracan group' of Maxillopoda which includes also the Ostracoda, Branchiura and Thecostraca (sensu Grygier, 1987).

Tantulocaridans are very uncommon in the Mediterranean but this should primarily be attributed to the low level of sampling effort in this area, rather than to any defined zoogeographical patterns. The only mediterranean find thus far, constitutes in fact the first record of a tantulocaridan,

* Contribution No. 452 of the Delta Institute for Hydrobiological Research, Yerseke. 
however, without having been recognized as such. In 1903 Bonnier described Cumoniscus kruppi on the basis of a single specimen, obviously a female, and referred the species to an unnamed family of epicaridean isopods. It was collected by dredging at $1000 \mathrm{~m}$ depth near the Isle of Capri, Italy. C. krup$p i$ was found attached to an undescribed species of Leuconidae and represents thus far the only published account of a cumacean-infesting tantulocarid. Boxshall \& Lincoln (1987) were unable to place the species in any of the existing families because of lack of detailed information (Bonnier did not give any illustrations) and because both the male and the tantulus are unknown. Hence, they ranked Bonnier's species as incertae sedis within the class and regarded the sac-like habitus and the anteriorly located, minute adhesive disc as sufficient evidence to keep $C$. kruppi in the Tantulocarida. Most recently Boxshall (pers. comm.) found a second cumacean-parasitizing tantulocaridan, probably belonging to Cumoniscus, from deep water in the Gulf of Biscay.

A single tantulus was caught from $1220 \mathrm{~m}$ depth in the Ligurian Sea (western Mediterranean), representing a new genus and species of Deoterthridae described below. It is the first record of a tantulus stage not found attached to a crustacean host, but living free in the sediment.

\section{Methods}

The holotype tantulus was examined as a temporary preparation in glycerin. All drawings were made under oil immersion using a Leitz Dialux 20 microscope with interference contrast. Judicious manipulation of the coverslip allowed careful examination of the detailed morphology of the thoracopods and the cephalon. After completing the description, the specimen was transferred to lactophenol mounting medium and the preparation was sealed with glyceel (Gurr ${ }^{\oplus}$, BDH Chemicals Ltd, Poole, England).

\section{Taxonomy}

Dicrotrichura gen. nov.

Diagnosis. - Class Tantulocarida. Family Deoterthridae. Tantulus larva comprising cephalon, 6 pedigerous somites, and a 2-segmented abdomen. First thoracic tergite largely concealed beneath posterior margin of dorsal cephalic shield. Cephalic shield triangular; ornamentation consisting of 4 anterior plus 6 posterior pairs of pores, surface lamellae absent. Cephalic stylet slightly curved in lateral view. Thoracopods 1 to 5 each with unsegmented protopod bearing a well developed medial endite. Exopod of thoracopods 1 to 5 apparently 1-segmented with 2 (leg 1), 3 (leg 2), or 4 setae (legs 3-5). Endopod 1-segmented with 0 (leg 1) or 2 setae (legs 2-5). Thoracopod 6 without distinct rami, with coupling spines on medial margin of protopod and 2 setae apically. Second abdominal somite with 3 transverse lamellae running around the somite. Caudal rami distinct, armed with 1 short and 2 long, bi-articulate setae. Host unknown.

Etymology. - The generic name is derived from the Greek dikroös, meaning forked, trichos, meaning hair, and oura, meaning tail and refers to the peculiarly shaped, caudal setae. Gender: feminine.

Type and only species. - Dicrotrichura tricincta spec. nov.

\section{Description}

Dicrotrichura tricincta spec. nov. (figs. 1A-B; 2A-E)

\section{Tantulus larva}

Body (figs. 1A-B) comprising a cephalon covered by a dorsal shield, 6 free thoracic somites, and a 2-segmented abdomen. Total body length about 83 $\mu \mathrm{m}$, measured from the tip of the cephalon to the posterior margin of the abdomen. Cephalon triangular, tapering anteriorly towards the oral disc; posterior margin straight with posterolateral angles represented by slightly pronounced lobes; ventrolateral margins with incision. Cephalic shield about 1.14 times longer than wide $(32 \mu \mathrm{m} \times 28 \mu \mathrm{m})$; two dorsal, longitudinal surface lamellae extend to the basis of the oral disc. The rostrum is absent. The oral disc is about $8.5 \mu \mathrm{m}$ in diameter and is posi- 

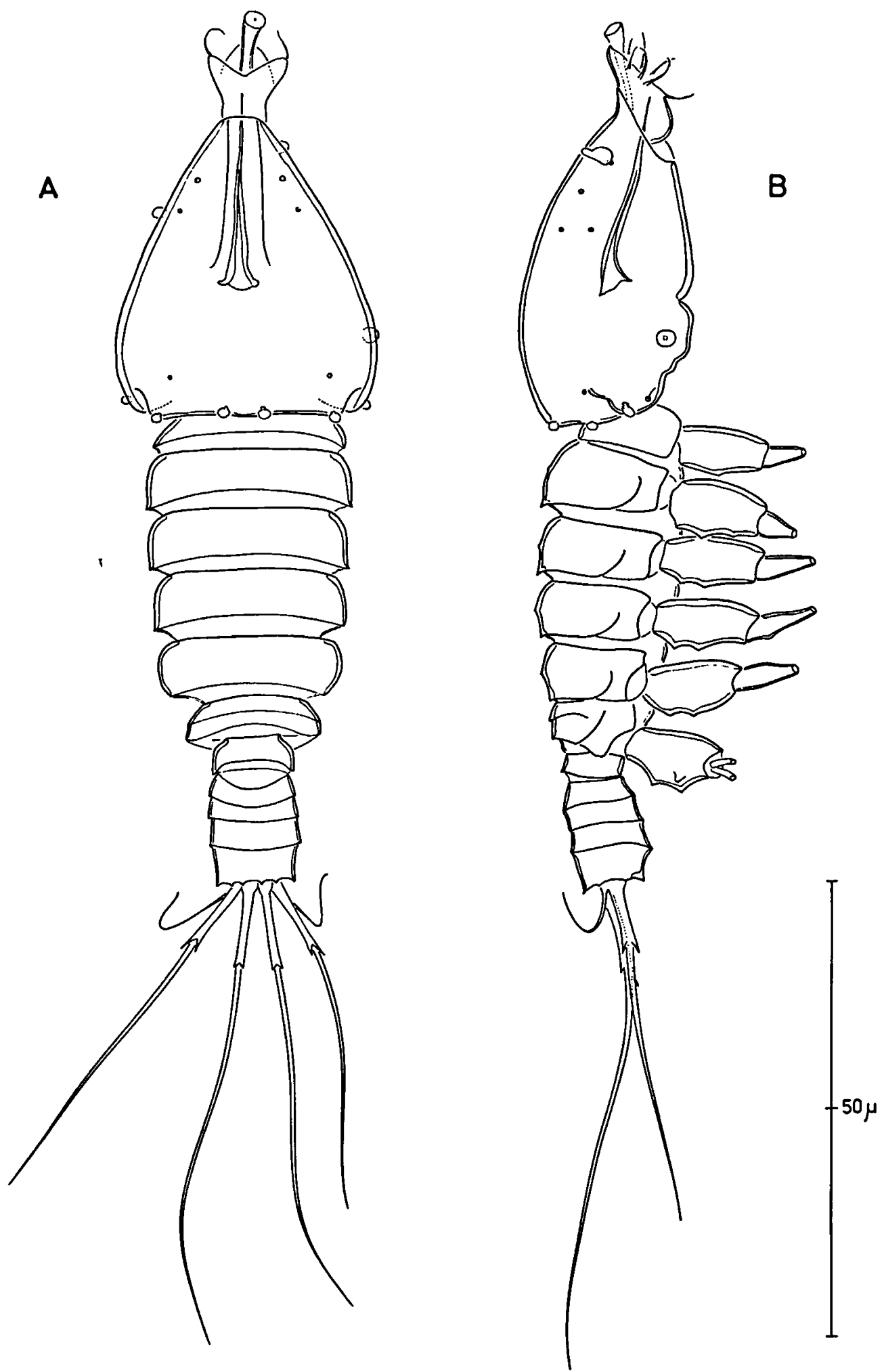

Fig. I. Dicrotrichura tricincta gen. et sp. n. A, holotype tantulus, dorsal view; B, same, lateral view (thoracopodal setae omitted). 
tioned far anteriorly so that it is visible in dorsal aspect; the disc is invaginated at the dorsal midline, the lateral margins each have 3 filament-like structures, the ventral margin forms a lobe-like extension which is basally directed. A peculiar funnelshaped organ is discernible near the middorsal incision of the oral disc; this slender, hollow structure has a minute pore apically and seems to run further internally towards a muscle-like strand which is comparable both in appearance and in position with the striated organ mentioned in earlier descriptions. Internal structures other than the cephalic stylet were too small for them to be described adequately. There are 10 pairs of simple pores on the shield; 4 pairs in the anterior part (on both sides arranged in the typical deoterthrid L-pattern) and 6 pairs around the posterior margin of which 1 pair is located subdorsally and another one surrounds a tiny sensillum; some of the pores were covered by small bulb-shaped bodies of hyaline substance. The ventral surface of the shield lacks pores and lamellae altogether. There are no cephalic appendages.

The cephalic stylet is about $22 \mu \mathrm{m}$ long and slightly curved both in dorsal and in lateral view. The tip of the stylet is extruded and does not taper to a very fine point. The base is hollow and provided with two lateral barbs.

The six free thoracic somites each have a well developed tergite, the first five lacking surface ornamentation, the last one with a transverse surface lamella; except for the sixth one all thoracic somites are equally broad and the thorax as a whole is distinctly narrower than the cephalon. The first tergite is largely concealed beneath the posterior rim of the cephalic shield. Each thoracic somite bears a pair of well developed thoracopods.

Thoracopod 1 (fig. 2A) biramous, with a large undivided protopod bearing a lobate medial endite at the proximal rim and a lobate proximal extension at the outer margin. Endite armature visible as one. spinous element (using light microscopy). The exopod is one-segmented and slightly longer than wide, distal part armed with two strong setae. Endopod represented by a digitiform segment bearing a small spinule.

Thoracopods 2 to 5 (figs. 2B-C) biramous, with large one-segmented protopod bearing medial en- dite proximally, two spiny processes along the outer margin and two spinous processes at the outer distal corner. Under light microscope a subapical spine and a blunt process are visible on the edite. Rami one-segmented. Exopod short, with two strong and one (leg 2) or two (legs 3-5) slender naked setae. Endopod one-segmented, long, with swollen basal part and a tapering thin-walled distal part; armed with two outer-margin setae laterally; apex with two processes, the outer one being spatulate.

Sixth thoracopod (fig. 2D) with simple protopod lacking medial endite, but bearing two coupling spines on the medial margin; outer margin with 3 spinous processes. Rami not distinct but possibly represented each by a vestige bearing a strong naked seta.

The abdomen (figs. $1 \mathrm{~A}-\mathrm{B} ; 2 \mathrm{E}$ ) is $15 \mu \mathrm{m}$ in length and two-segmented. The first abdominal somite is 2.9 times wider than long $(8.7 \mu \mathrm{m} \times 3 \mu \mathrm{m})$, the second 1.2 times longer than wide $(12 \mu \mathrm{m} \times 10$ $\mu \mathrm{m})$. First somite without surface ornamentation. Second somite tapering anteriorly; ornamented with 3 ring-shaped transverse lamellae giving the somite a 4-segmented appearance. Ventral posterior border of abdomen with two spinous processes, covering paired combs consisting of several fine spinules, the tips of which are not extending beyond rear margin of caudal rami; dorsal hind margin armed with two pairs of minute spinous processes. Caudal rami very small, weakly defined; armed each with one short lateral seta and two long medial setae; medial setae consisting of strong basal part with swollen basis and bifid apex with which the slender, flagella-like, distal part articulates.

\section{Adult male and female: unknown.}

Material. - A single tantulus was found during sorting of meiofauna from a sampling site $\left(42^{\circ} 41^{\prime} 06^{\prime \prime} \mathrm{N}, 08^{\circ} 38^{\prime} 30^{\prime \prime} \mathrm{E}\right.$; depth $1220 \mathrm{~m}$ ) in the Ligurian Sea (western Mediterranean), northwest of the Bay of Calvi (Corsica). The bottom sample was taken on 18 September 1985 with a small, modified Reineck box corer $\left(170 \mathrm{~cm}^{2}\right)$ by Dr K. Soetaert. The median grain size of the sediment is below $3 \mu \mathrm{m}$ and the silt-clay amount averages $92 \%$. The CPE (Chloroplastic Pigment Equivalent) value is about 0.56 $\mu \mathrm{g} / \mathrm{cm}^{2}$ of which $13.2 \%$ is represented by chl a. Accompanying meiofauna includes nematodes, harpacticoid copepods, foraminiferans, gastrotrichs, annelids, loriciferans, sipunculids, 


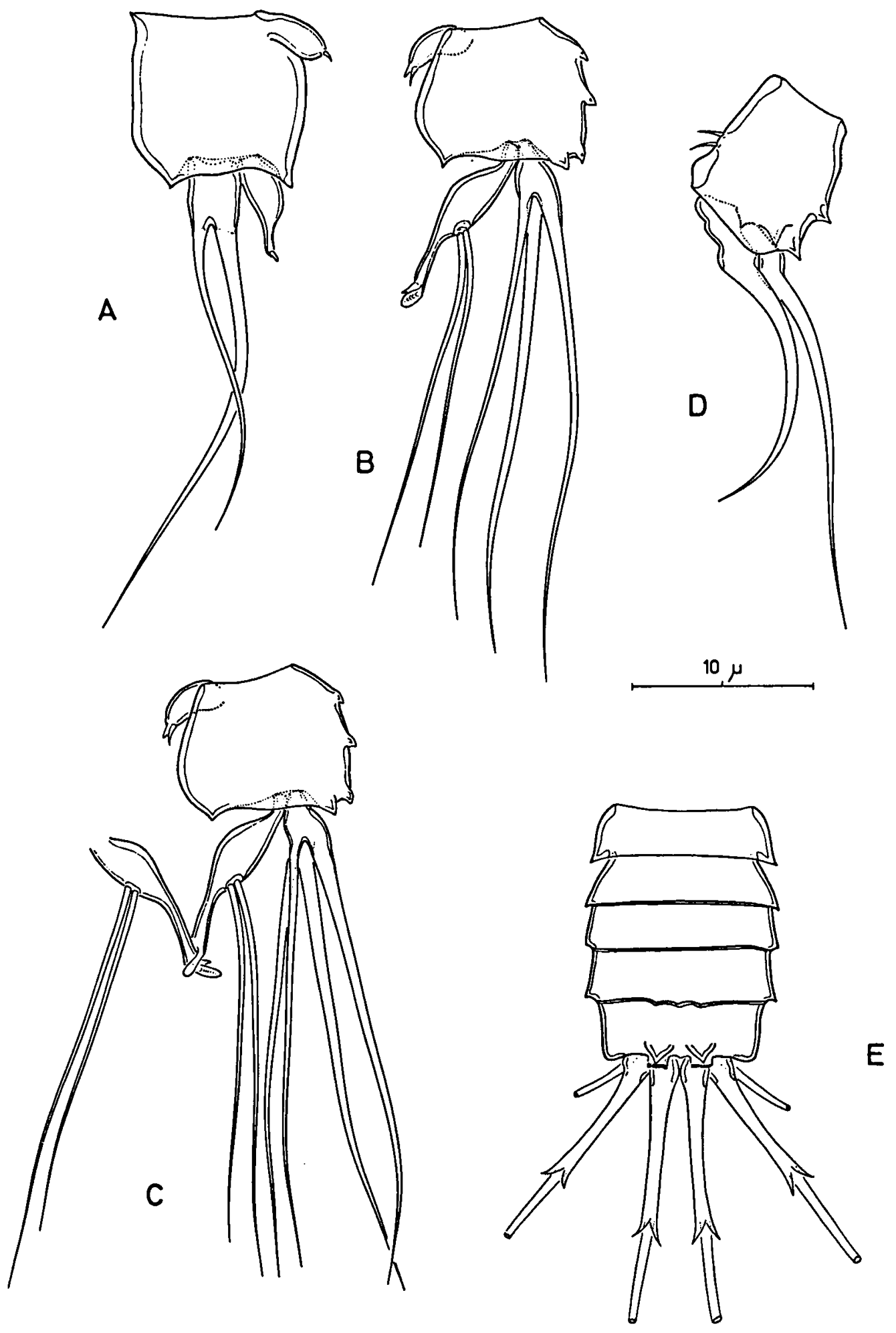

Fig. 2. Dicrotrichura tricincta gen. et sp. n., holotype tantulus. A, first thoracopod; B, second thoracopod; C, third thoracopod; D, sixth thoracopod; E, abdomen, ventral view. 
tardigrades, ostracods, kinorhynchs and turbellarians. The holotype is deposited in the British Museum (Natural History), London.

Etymology. - The trivial name is derived from the Latin tres, tria. meaning three, and cinctus, meaning belt, and refers to the three transverse lamellae on the second abdominal somite.

\section{Discussion}

Dicrotrichura tricincta is the smallest tantulocaridan recorded thus far, its body length $(83 \mu \mathrm{m})$ being less than half the size of the isopod-infesting Doryphallophora megacephala (Boxshall \& Lincoln). All other species that measure less than $100 \mu \mathrm{m}$ are known to parasitize exclusively harpacticoid copepods: Basipodella harpacticola Becker $(85 \mu \mathrm{m})$, Stygotantulus stocki Boxshall \& Huys $(94 \mu \mathrm{m})$, Boreotantulus kunzi Huys \& Boxshall $(98 \mu \mathrm{m})$ and Campyloxiphos dineti Huys $(95 \mu \mathrm{m})$. In terms of size harpacticoids represent the smallest host category for tantulocaridans, suggesting that there might be a relationship between the size of the host and the body length of the infective stage.

D. tricincta is also the only tantulocaridan that was found free in the sediment instead of being firmly attached to a host. Potential crustacean hosts found in the same sample included harpacticoid copepods and ostracods but none of the specimens were found to be infested, indicating that the tantulus was not detached from the host's integument during the process of meiofauna extraction (centrifugation floatation technique; Heip et al., 1985). The cephalic stylet, unlike that of tantulocaridans known from attached tantuli, definitely protrudes through the central pore of the oral adhesive disc. In $D$. tricincta the internal tissue appears to be arranged symmetrically around the stylet which occupies a medial position in the cephalon. In previous descriptions the stylet is often reported to lie near the ventral wall of the head and sometimes its orientation varies within the same species (Doryphallophora harrisoni for instance; cf. Boxshall \& Lincoln, 1987). The internal structures located around the piercing organ of $D$. tricincta were too small to be described adequately but their absence in other tantulocaridans suggests that they aid in holding the stylet in its central position during penetration of the host's integument and degenerate immediately when the internal tissue reorganizes during metamorphosis towards the adult male or female. A peculiar funnel-shaped organ was discerned near the dorsal margin of the adhesive disc. Furthermore, both lateral sides of the disc possess a series of 3 filament-like structures. None of these structures were observed during SEM observation of the inner surface of the oral disc of Boreotantulus kunzi (cf. Huys \& Boxshall, 1988) but again this was based on tantuli which had been successfully detached from the host. It is impossible to homologise these 'oral' structures with cephalic appendages of other maxillopodans as Becker (1975) and Bradford \& Hewitt (1980) have suggested before. Being located anteriorly it is likely that these structures function as sense organs for detecting a suitable host. This would explain their absence in attached specimens since the juvenile tantulus is believed to be attached permanently during life till the development is completed. Clearly, once firmly attached the infective stage is not able to infect another, possibly more suitable host, or to re-infest the same host at a different place on the integument, because the muscles associated with the cephalic stylet (penetration) and the thoracopods (locomotion) degenerate and/or are probably reorganized immediately after successful attachment. It follows that the detailed morphology of the tantulus is more complex than previously expected.

The new genus is placed in the Deoterthridae as redefined by Huys (in press). The latter author excluded the isopod-infesting members of the genus Deoterthron and referred them to a separate genus Doryphallophora Huys in the newly established family Doryphallophoridae. The removal of these species solved the problematic status of Austrotantulus Boxshall [= Deoterthron] (Boxshall, 1988; Huys \& Boxshall, 1988) and narrowed considerably the familial diagnosis of the Deoterthridae, now embracing Deoterthron, Boreotantulus Huys \& Boxshall and Campyloxiphos Huys. The genus Dicrotrichura can easily be included in this series because of its juvenile characters. These include the 
absence of a rostrum, the cephalic shield with 10 pairs of pores (4 anteriorly, 6 posteriorly), the presence of 2 setae on the exopod of leg 1 and the two-segmented abdomen. The detailed arrangement of the cephalic pores is exactly the same as described for other deoterthrid genera and reinforces the significance of this character in diagnosing higher level taxa in the Tantulocarida (Huys, in press). The presence of small bodies of substance extruded from some of these pores might indicate their secretory role.

The bi-articulated caudal setae, showing a junction between the furcate proximal part and the distal flagella, are unique to Dicrotrichura. It is worthy to note that the caudal setae of Campyloxiphos dineti show a slight swelling at about the same site of this articulation. In all known tantulocaridans the thoracopodal setation is identical on legs 2 to 5 but in Dicrotrichura the second thoracopod is different from legs $3-5$. The new genus differs also from the other Deoterthridae in the ring-shaped lamellae on the second abdominal somite. Campyloxiphos and Boreotantulus exhibit a similar abdominal surface ornamentation but here the lamellae are arranged transversely only in dorsal aspect; however, laterally and ventrally they are joined by short longitudinal lamellae. No distinct surface lamellae were found in both Deoterthron species. $D$. tricincta is similar to $C$. dineti in the setation of the 3 rd to 6 th thoracopods. The new species however, possesses a well defined asetose endopod on leg 1 and an almost straight cephalic stylet whilst the latter exhibits a uniramous first thoracopod (endopod absent) in combination with an unusual sigmoid stylet. The presence of 5 setae on thoracopods 2 to 5 , the slightly ornamentend abdomen and the lateral, serrate, caudal spine serve to distinguish Deoterthron from Dicrotrichura. Boreotantulus differs from the new genus primarily in the unusual exopodal setation of the thoracopods, showing only 2 setae on legs $2-5$ but 3 setae on leg 1 . The familial allocation currently suggests that $D$. tricincta parasitises either harpacticoids or ostracods.

\section{Acknowledgements}

Grateful thanks are due to Dr Karline Soetaert for providing me with the tantulocaridan material. Part of this research was carried out under EEC Science Grant No. ST2*0443.

\section{References}

Becker, K.-H., 1975. Basipodella harpacticola n.gen., n.sp. (Crustacea, Copepoda). Helgol. wiss. Meeresunters., 27: 96-100.

Bonnier, J., 1903. Sur deux types nouveaux d'Épicarides parasites d'un Cumacé et d'un Schizopode. C. r. hebd. Séances Acad. Sci. Paris, 136: 102-103.

Boxshall, G.A., 1988. A new genus of tantulocaridan (Crustacea: Tantulocarida) parasitic on a harpacticoid copepod from Tasmania. Bull. Brit. Mus. (nat. Hist.), D54: 270-274.

Boxshall, G.A. \& R. Huys, 1989. New tantulocarid, Stygotantulus stocki, parasitic on harpacticoid copepods, with an analysis of the phylogenetic relationships within the Maxillopoda. J. crust. Biol., 9: 126-140.

Boxshall, G.A. \& R.J. Lincoln, 1983. Tantulocarida, a new class of Crustacea ectoparasitic on other crustaceans. J. crust. Biol., 3: 1-16.

Boxshall, G.A. \& R.J. Lincoln, 1987. The life cycle of the Tantulocarida (Crustacea). Phil. Trans. r. Soc. London, B315: 267-303.

Bradford, J.M. \& G.C. Hewitt, 1980. A new maxillopodan crustacean, parasitic on a myodocopid ostracod. Crustaceana, 38: 67-72.

Grygier, M.J., 1987. New records, external and internal anatomy, and systematic position of Hansen's y-larvae (Crustacea: Maxillopoda: Facetotecta). Sarsia, 72: 261-278.

Grygier, M.J. \& J. Sieg, 1988. Microdajus (Crustacea: Tantulocarida) parasitic on an Antarctic tanaidacean, and a range extension of M. langi Greve. J. nat. Hist., 22: 1495-1505.

Heip, C., M. Vincx \& G. Vranken, 1985. The ecology of marine nematodes. Oceanogr. mar. Biol. ann. Rev., 23: 399-489.

Huys, R., in press. Campyloxiphos dineti gen. et spec. nov. from off Namibia and a redefinition of the Deoterthridae Boxshall \& Lincoln (Crustacea: Tantulocarida). J. nat. Hist. (in press).

Huys, R. \& G.A. Boxshall, 1988. A new genus and species of tantulocaridan (Crustacea: Tantulocarida) parasitic on a harpacticoid copepod from the Skagerrak. Sarsia, 73: 205-211.

Starobogatov, Ya.I., 1986. Systematics of Crustacea. Zool. Zh., 65: 1769-1781. [In Russian, with English summary.]

Received: 27 September 1989 